\title{
Starting-up unregistered and firm performance in Turkey
}

\author{
Colin C. Williams ${ }^{1}$ - Abbi M. Kedir ${ }^{1}$
}

Published online: 24 November 2016

(C) The Author(s) 2016. This article is published with open access at Springerlink.com

\begin{abstract}
Recent years have seen a questioning of the negative representation of informal sector entrepreneurship and an emergent view that it may offer significant benefits. This paper advances this rethinking by evaluating the relationship between business registration and future firm performance. Until now, the assumption has been that starting-up unregistered is linked to weaker firm performance. Using World Bank Enterprise Survey data on 2494 formal enterprises in Turkey, and controlling for other determinants of firm performance as well as the endogeneity of the registration decision, the finding is that formal enterprises that started-up unregistered and spent longer unregistered have significantly higher subsequent annual sales and productivity growth rates compared with those registered from the outset. This is argued to be because in such weak institutional environments, the advantages of registering from the outset are outweighed by the benefits of deferring business registration and the low risks of detection and punishment. The resultant implication is that there is a need to shift away from the conventional eradication approach based on the negative depiction of informal entrepreneurship as poorly performing, and towards a more facilitating approach that improves the benefits of business registration and tackles the systemic formal institutional deficiencies that lead entrepreneurs to decide to delay the registration of their ventures.
\end{abstract}

Keywords Entrepreneurship - Informal sector - Firm performance · Venture creation · Turkey

Colin C. Williams

C.C.Williams@sheffield.ac.uk

Abbi M. Kedir

a.m.kedir@sheffield.ac.uk

1 Sheffield University Management School, University of Sheffield, Conduit Road, Sheffield S10 1FL, UK 


\section{Introduction}

Recently, a small but burgeoning literature has begun to tentatively explore more positive representations of informal sector entrepreneurship, by which is here meant starting-up and/ or owning and managing a business venture which does not register with and/or declare some or all of their production and/or sales to the authorities for tax, benefit and/or labour law purposes when they should do so (Ketchen et al. 2014; McKenzie and Sakho 2010; Siqueira et al. 2014; Williams and Shahid 2015; Williams et al. 2013, 2015). The aim of this paper is to advance this emerging re-representation of informal sector entrepreneurship by evaluating the impacts of delaying business registration on firm performance. Until now, informal entrepreneurship has been widely depicted in a negative manner as poorly performing unproductive endeavour, which is deleterious to economic development and growth (Baumol 1990; La Porta and Shleifer 2008, 2014). By showing how formal enterprises that start-up unregistered and spend longer unregistered in Turkey gain significant advantages, enabling them to subsequently become higher-performing enterprises than their counterparts that started-up registered, the intention is to start to question this dominant negative depiction and to open up informal entrepreneurship to re-representation as a more positive phenomenon than so far considered.

Reporting World Bank Enterprise Survey (WBES) data on the relationship between informal entrepreneurship and firm performance in Turkey, this paper therefore advances understanding of informal entrepreneurship in three ways. Empirically, the widespread a priori assumption that starting-up unregistered has a negative impact on firm performance is tentatively refuted by showing how sales and productivity growth rates are significantly higher in formal enterprises that started-up unregistered than those registered from the outset in Turkey. Theoretically, therefore, this significant positive association between being unregistered at start-up and firm performance not only provides validation for a more positive representation of informal entrepreneurship but also tentatively displays that in weak institutional environments, the advantages of business registration are outweighed by the benefits of non-registration and low risks of detection and punishment. Finally, and from a policy perspective, the significant impact is to demonstrate the need for a shift away from the conventional eradication approach based on the negative depiction of informal entrepreneurship as poorly performing endeavour, and towards a more positive facilitating approach that improves the benefits resulting from business registration and tackles the systemic formal institutional deficiencies that lead entrepreneurs to start-up their ventures on an unregistered basis.

To do this, the first section frames the contributions of this paper to the entrepreneurship literature by outlining the burgeoning literature on informal entrepreneurship and the emergent shift from a negative to a more positive depiction of such entrepreneurship. Given this, the second section focuses upon the relationship between informal entrepreneurship and firm performance, reviewing the conventional depiction of nonregistration as negatively affecting firm performance followed by the rationales for conversely viewing nonregistration as beneficial to subsequent firm performance. To evaluate the resultant propositions regarding the relationship between firm performance and startingup unregistered, the third section introduces the data, namely World Bank Enterprise Survey (WBES) harmonised data on 2494 enterprises in Turkey and modelling framework here employed. In the fourth section, we present the results. Finding evidence that formal enterprises that started-up unregistered and spent longer unregistered have 
significantly higher subsequent annual sales and productivity growth rates than those registered from the outset, the fifth and final section discusses the theoretical and policy implications along with the limitations of this study and future research required.

\section{Perspectives towards of informal entrepreneurship}

For much of the twentieth century, informal entrepreneurship was largely deemed unimportant and unworthy of scholarly attention. A modernisation theory prevailed that depicted informal endeavour as some minor and declining remnant of an earlier mode of production and its continuing persistence in countries as signalling their 'underdevelopment' and 'backwardness' (Lewis 1959; Geertz 1963; Gilbert 1998). The widespread belief was that such endeavour would naturally and inevitably disappear with economic advancement and modernisation. Over the past few decades however, the informal sector in general, and informal entrepreneurship more particularly, has been recognised as an extensive and persistent feature of the economic landscape (Schneider and Williams 2013; ILO 2013; Williams 2015a, b). Indeed, two-thirds of businesses in developing countries have been shown to be unregistered at start-up (Autio and $\mathrm{Fu} 2015$ ). This recognition of the extensiveness of informal entrepreneurship has led to the emergence of a burgeoning literature and new theorisations of such entrepreneurship.

Firstly, some have sought to update conventional modernisation theory (La Porta and Shleifer 2008, 2014). Although the extensiveness of informality is now recognised, this nonetheless retains the depiction of two disconnected sectors and a negative representation of informal entrepreneurs as typically uneducated people operating small unproductive enterprises in separate 'bottom of the pyramid' markets producing lowquality products for low-income consumers using little capital and adding little value (La Porta and Shleifer 2014). A second loose grouping of scholars adopting a structuralist perspective however, recognises that the formal and informal spheres are not disconnected. Instead, the growth of informal entrepreneurship is deemed an inherent feature and direct by-product of a deregulated open world economy where outsourcing and subcontracting have become ways of integrating informal enterprises into contemporary capitalism so as to reduce production costs (Castells and Portes 1989; Davis 2006; Meagher 2010; Slavnic 2010; Taiwo 2013). Nevertheless, although recognising informal entrepreneurship as inter-twined with the formal realm, it remains seen as a negative phenomenon.

In both the modernisation and structuralist perspectives, therefore, economies are viewed as losing 'natural' competitiveness because productive formal enterprises suffer unfair competition from unproductive informal enterprises (Leal Ordóñez 2014; Lewis 2004). Governments are viewed as losing both regulatory control over work conditions (ILO 2014) and tax revenue (Bajada and Schneider 2005), and customers as lacking legal recourse and certainty that health and safety regulations have been followed (Williams and Martinez-Perez 2014b). Informal entrepreneurs, meanwhile, are viewed as 'necessitydriven' (Castells and Portes 1989), lacking access to capital, credit and financial services (ILO 2014), which when combined with their need to keep the business small to avoid the authorities (Williams et al. 2012), lack of advice and support (Barbour and Llanes 2013) and an inability to secure property rights (De Beer et al. 2013), mean that they become locked in a 'poverty trap' (McKenzie and Woodruff 2006). 
Recently however, alternative more positive discourses have emerged. The ability of informal entrepreneurs to create jobs has been viewed as a potential benefit for developing economies and governments (Ketchen et al. 2014) and this sphere has started to be seen as a breeding ground for the micro-enterprise system (Barbour and Llanes 2013). Formal enterprises are viewed as potentially benefiting from cheaper sources of labour and raw materials (Ketchen et al. 2014), potential formal entrepreneurs from the opportunity to use this realm as a test-bed for their business ventures (Williams and Martinez-Perez 2014a) and informal entrepreneurs from this escape route from corrupt public officials and the regulatory burden in contexts where this stifles business development (Tonoyan et al. 2010). Customers especially in 'base of the pyramid' markets, meanwhile, are seen as potentially benefiting from more affordable goods and services (Ketchen et al. 2014; London et al. 2014).

A catalyst for this more positive representation has been recognition that informal entrepreneurship is not always necessity-driven but often a matter of choice (Cross 2000; Franck 2012; Gërxhani 2004; Maloney 2004; Perry and Maloney 2007; Williams 2009; Williams and Gurtoo 2012; Williams and Youssef 2015). The resultant agencyoriented theorisations of informal entrepreneurship are of two broad varieties. On the one hand, a group of 'legalist' scholars depict informal entrepreneurs as rational economic actors who, after weighing up the costs of informality and benefits of formality, decide not to operate in the formal economy. Informal entrepreneurship is more prevalent in developing than developed countries therefore, due to formalisation having higher costs (e.g., time and effort to formally register, burdensome regulations, compliance costs) and fewer benefits (De Soto 1989, 2001; Nwabuzor 2005), which commonly result in the costs of formalising not exceeding the benefits (Cross 2000).

On the other hand, and drawing inspiration from institutional theory (North 1990), another agency-oriented group of scholars adopting a more 'social actor' approach, view informal entrepreneurship as occurring outside of formal institutional prescriptions but within the norms, values and beliefs of informal institutions and therefore as socially legitimate endeavour (Kistruck et al. 2015; Siqueira et al. 2014; Webb et al. 2009). Informal entrepreneurship thus results from formal institutional deficiencies, such as relatively weak legal and contract enforcement systems (Puffer et al. 2010; Sutter et al. 2013), and/or 'because of the incongruence between what is defined as legitimate by formal and informal institutions' (Webb et al. 2009: 495). If symmetry exists between formal and informal institutions, informal entrepreneurship only occurs unintentionally (e.g., due to a lack of awareness of the codified laws and regulations). When formal and informal institutions do not align however, the result is more informal entrepreneurship (De Castro et al. 2014; Kistruck et al. 2015; Siqueira et al. 2014; Vu 2014; Webb et al. 2013, 2014). Indeed, the greater the degree of asymmetry, the greater the level of informal entrepreneurship (Williams and Horodnic 2015; Williams and Shahid 2015).

Until now, however, and despite this emergence of more positive representations of informal entrepreneurship, few if any scholars have questioned the view that informal entrepreneurship is associated with weaker firm performance.

\section{Informal entrepreneurship and firm performance}

For many years, informal entrepreneurship has been seen as poorly performing endeavour relative to formal entrepreneurship (ILO 2007; Farrell 2004; Palmer 2007). This poorer 
performance thesis prevails to varying extents across all representations of informal entrepreneurship. Firstly, modernisation theory, views informal enterprises as hugely inefficient compared with formal enterprises, operating in different 'bottom of the pyramid' markets and unlikely to be capable of charging lower prices for the same products (La Porta and Shleifer 2008, 2014). Secondly, the structuralist approach views the informal sector as a refuge where necessity-driven low-productivity firms, requiring low levels of start-up capital, stay small to avoid detection and lack the scale to produce efficiently, although the cost advantages gained by avoiding taxes and regulations more than offsets their low productivity and small scale (Farrell 2004; Palmer 2007). Perhaps surprisingly, this poorer performance thesis also persists among scholars adopting more positive agency-oriented perspectives. The rational economic actor and social actor explanations depict informal entrepreneurship as less productive than formal enterprises and as resulting from the general failure of 'weak' institutions to provide sufficient resources to warrant formalisation (De Soto 1989; Kistruck et al. 2015; Wunsch-Vincent et al. 2015).

To support this consensus that informal enterprises are worse performing than their formal counterparts, most scholars cite the seminal study by La Porta and Shleifer (2008: 344) who find that 'Productivity is much higher in small formal firms than in informal firms, and it rises rapidly with the size of formal firms'. This conclusion is reached by analysing World Bank Informal Surveys in 13 countries and Micro-Enterprise Surveys in 14 countries (19 in Africa, six in Asia and two in Latin America). The average Informal Survey comprised 31 registered and 192 unregistered firms, and the average MicroEnterprise Survey 137 registered and 77 unregistered enterprises (i.e., the total sample was 2321 registered and 3574 unregistered enterprises). The non-representative sampling strategy in each country was that 'World Bank contractors identified neighborhoods perceived to have a large number of informal firms' (La Porta and Shleifer 2008: 295). Based on this small unrepresentative sample, statistically significant differences are found in the performance of registered and unregistered enterprises in 10 of the 25 countries on value added per employee at the 0.1 level (and four countries at the 0.01 level), 17 of the 26 countries on sales per employee at the 0.1 level (and 12 at the 0.01 level), and in 18 of the 26 countries on output per employee at the 0.1 level (12 at the 0.01 level). Hence, significant variations in firm performance are far from universal. Indeed, unregistered enterprises outperformed registered enterprises in six of the 25 countries on value added per employee, three of the 26 countries on sales per employee and four of the 26 on output per employee (see La Porta and Shleifer 2008: Tables 13 and 14). More importantly, they explicitly state that the overall productivity gap disappears and 'unregistered firms are not unusually unproductive once we take into account their expenditure on inputs, the human capital of their top managers, and their small size' (La Porta and Shleifer 2008: 335).

Similar weak evidence exists in the few other studies of this poorer performance thesis (Fajnzylber et al. 2009; Farrell 2004; McKinsey Global Institute 2003). For example, although Fajnzylber et al. (2009) claim that Mexican firms paying taxes exhibit between 15 and $60 \%$ higher 'productivity' levels, their measure of productivity is profit levels and self-employment income and they do not control for the full range of firm-level determinants influencing firm productivity and performance.

This poorer performance thesis, and importantly for this paper, has been similarly assumed to apply to formal enterprises which start-up unregistered relative to enterprises registered from the outset. As La Porta and Shleifer (2008: 279) assert, 'the differences in productivity between formal and informal firms are so large that it is hard to believe that 
simply registering unregistered firms would eliminate the gap.' The only known comparison of the firm performance of formal enterprises starting-up unregistered compared with enterprises registered from the outset of operations, nevertheless, is a study of World Bank survey data on 355 unregistered start-ups across seven Latin American countries (104 in Colombia, 72 in Argentina, 72 in Bolivia, 66 in Mexico 20 in Peru, 12 in Uruguay and nine in Panama). Perry et al. (2007: 173) find that unregistered start-ups 'at least initially, exhibit on average, much lower levels of output per worker, after controlling for firm size, time in business, sector and region'. However, this is a small sample, the productivity gap is statistically significant in only four of the seven countries studied and the headline average national figure of $29 \%$ lower productivity for unregistered start-ups is heavily skewed by the Peru figure where the productivity gap is over $50 \%$, is not statistically significant, and only 20 unregistered start-ups were surveyed. Given the strong consensus but weak evidence-base, we here revisit this supposedly negative relationship between nonregistration at start-up and firm performance.

Conventionally, therefore, formal enterprises starting-up unregistered have been viewed as subsequently worse performing than those who register from the outset. However, recognising that many entrepreneurs operate unregistered out of choice (Gërxhani 2004; Maloney 2004; Perry and Maloney 2007; Williams and Youssef 2015), and adopting a more agency-oriented perspective, the opposite could be argued; that formal enterprises who start-up unregistered subsequently outperform enterprises registered from the outset. This is because those formal enterprises that remain unregistered during their start-up phase at least initially avoid paying taxes, burdensome regulations and the additional costs imposed on formal enterprises by corrupt public sector officials for example, and thus appear to possess many of the pre-requisites to outperform the enterprises that suffer such constraints from the very start of their business venture. As La Porta and Shleifer (2014) assert, formal firms have to pay taxes and comply with regulations, so they have a huge costs disadvantage relative to those unregistered at start-up. Operating initially unregistered therefore, might well positively influence subsequent firm performance. Moreover, if registration does not open up access to a wide range of benefits of formality, such as public goods provision by government and access to credit to expand existing establishments, then the costs of registration will outweigh the benefits. Until now, however, few if any studies have evaluated the proposition that there is better subsequent firm performance by formal enterprises that started-up unregistered compared with those that registered from the outset. The main rationale to test whether the performance of unregistered firms at startup is to contribute to the extant literature which predominantly paints a negative picture about them. To begin to do so therefore, the following hypothesis can be tested:

Hypothesis 1: Controlling for key determinants of firm performance and the endogeneity of registration status, enterprises starting-up unregistered and then registering display better levels of firm performance than those starting-up registered.

Similarly, competing views exist on whether and how the length of time that a formal enterprise spent unregistered influences future firm performance. On the one hand, and from the perspective that unregistered enterprises are worse performing, it might be posited that this will further diminish future firm performance. Unable to grow and 
expand due to limited access to credit and loans, and the need to remain small in order to avoid the authorities (Farrell 2004; Palmer 2007), the longer they remain unregistered the worse will be the firm performance of a formal enterprise that spent a longer time period unregistered compared with an enterprise that was registered from the outset.

On the other hand however, and from the perspective that being unregistered at startup improves subsequent firm performance, it could be argued that the longer they spend unregistered before registering, the greater will be their advantage over those registering from the outset. This is because the longer they remain freed from paying taxes, burdensome regulations and corruption in the public sector for example, the more the advantages that allow them to outperform their counterparts starting-up registered are consolidated and the greater will be the differential. This may be particularly pertinent in contexts where 'weak' formal institutions fail to provide sufficient resources to warrant formalisation (Kistruck et al. 2015; Wunsch-Vincent et al. 2015) and the costs thus outweigh the benefits of registration (e.g., access to credit, opportunities to engage with large firms and procure government contracts, reduced harassment by officials, and access to broader training and support programs). Although in mature formal institutional environments, therefore, there may be a point for a firm where the benefits of registration outweigh the costs of continuing unregistered, this is less likely in countries with weak formal institutions and the benefits of registration are fewer (De Mel et al. 2012; Thai and Turkina 2014). As such, highlighting the importance of the duration of staying unregistered at start-up, the following hypothesis can be tested:

Hypothesis 2: Controlling for key determinants of firm performance and the endogeneity of registration status, the longer start-ups spend unregistered before registering, the higher is their performance.

\section{Modelling framework}

Whether enterprises register or not at the outset can be conceived as an endogenous choice. Therefore, our sample of formal enterprises that either registered or not at the start of operations is a sample that is not random but rather, a sample with a systematic pattern of registration. Hence, if we model the determinants of firm performance conditional on their registration status and other relevant correlates without addressing the potential problem of sample selection bias, our estimates will not be reliable. In this paper, a Heckman two-step estimator (i.e., the Heckit estimator) is adopted to generate our econometric estimates. Simply put, the indicators of firm performance in Turkey will be regressed on a number of determinants controlling for the problem of sample selection bias.

Our primary equation (the equation of primary interest) that models the determinants of firm performance can be written as;

$$
p_{i}^{*}=x_{1 i}^{\prime} \beta_{1}+\varepsilon_{1 i}
$$

Where $x_{1 i}$ denotes a vector exogenous/control variable and $p_{i}^{*}$ represents firm I's performance (i.e. as captured by sales, employment and productivity growth). The performance indicators are observed for these formal firms that were both registered 
and unregistered at start-up and spent different lengths of time. When appropriate, Eq. (1) can be specified in terms of $\log$ of $\left(p_{i}^{*}\right)$.

To describe whether a firm is registered or not, a second equation (i.e. the selection equation) can be specified as;

$$
R_{i}^{*}=x_{2 i}^{\prime} \beta_{2}+\varepsilon_{2 i}
$$

with the following observation rule;

$$
\begin{aligned}
& p_{i}^{*}=p_{i}, R_{i}=1, \text { if } R_{i}^{*}>0 \\
& \& R_{i}=0 \text { if } R_{i}^{*} \leq 0
\end{aligned}
$$

$R_{i}$ is a binary variable indicating registration status which assumes a value of 1 when a firm starts operation with registration and takes a value of 0 otherwise. Therefore, Eq. (2) can be estimated using a standard probit model which is appropriate to predict the probability of registration based on a maximum likelihood (ML) estimation technique. This constitutes the first stage of estimation. The second stage of estimation is conducted using Eq. (1) after including the selectivity correction term generated at the first probit stage of the estimation. The specification is completed by making a distributional assumption on the error terms of the primary and selection equations. We assume that $\varepsilon_{1 i}$ and $\varepsilon_{2 i}$ follow a bivariate normal distribution with expectations zero and constant variances given as $\sigma_{1}^{2}$ and $\sigma_{2}^{2}$ respectively. The covariance of the errors is given as $\sigma_{12}$.

After controlling for self-selection, the second stage regressions enable us to test the two hypotheses. The WBES collects data using a stratified random sample of non-agricultural formal private sector businesses with five or more employees which is stratified by firm size, business sector and geographic region. The firm size strata in the WBES are 5-19 (small) 20-99 (medium), and 100+ employees (large-sized firms), while sector is broken down into manufacturing, services, transportation and construction. Public utilities, government services, health care, and financial services sectors are not included. Geographical regions within the country are selected based on which cities/regions collectively contain the majority of economic activity. The sampling frame is derived from the universe of eligible firms, normally obtained from the country's statistical office or another government agency such as the tax or business licensing authorities.

To collect data, a harmonised questionnaire is used across all countries, answered by some 1200-1800 business owners and top managers in larger economies such as Turkey, 360 in medium-sized economies and 150 in smaller economies. Although 135 countries are covered by the WBES and data is available from 2002 to 2014, the observed sample here is restricted to Turkey which has WBES data for 2008 to 2013.

\section{Dependent variables}

There are three key firm performance measures which serve as our dependent variables and are expressed in terms of logs, namely: (1) Real annual sales growth (using GDP deflators) (\%): All values for sales are converted to USD using the exchange rate in the corresponding fiscal year of the survey. Sales are deflated to 2009 using the USD deflator; (2) Annual employment growth (\%) computed as the change in full-time 
employment reported in the current fiscal year from a previous period. And (3) Annual productivity growth (\%): this is a derived variable that measures annualised growth in labour productivity where labour productivity is real sales (using GDP deflators) divided by full-time permanent workers. Annual productivity growth is the change in labour productivity reported in the current fiscal year from a previous period. For most countries the difference between the two fiscal year periods is two years. However, for some countries the interval is three years. Hence, an annualised measure is used. The use of the three indicators is important to show the reliability and robustness of our findings. The hypotheses we put forward will be tested and the results will be checked whether they hold regardless of the measure used.

\section{Key independent variables}

To evaluate the influence of informal entrepreneurship on future firm performance, two indicators are used: (1) Started unregistered: A firm-level measure that examines responses to the question, 'Was this establishment formally registered when it began operations?'. This is a dummy variable with value 1 indicating that the firm started operations in the country without formal registration and 0 when the firm was formally registered, and (2) Years unregistered: A continuous variable counting the number of years the firm operated without formal registration. This variable has value 0 for those firms operating formally since start-up. It is computed by analysing the responses to three questions: 'In what year did this establishment begin operations?', 'Was this establishment formally registered when it began operations?' and 'In what year was this establishment formally registered?'. The average number of years formal firms operated without registration is computed only for firms stating they were not formally registered when they started operations in the country.

\section{Control variables}

To measure whether formal enterprises that started-up and spent varying amounts of time unregistered witness different levels of firm performance than enterprises registered from the outset, it is necessary to control for other key determinants of firm performance. Here, other characteristics are examined which previous studies reveal to significantly influence firm performance, namely firm size, legal status and ownership structure, export orientation, sector, access to finance, the level of technological innovation, human capital factors and other business environment factors.

Firm size is viewed as determining firm performance, with larger firms performing better than smaller ones (Hsieh and Olken 2014; La Porta and Shleifer 2014), not least due to the lower average unit costs in larger firms. Firm size is a categorical variable with value 1 for small firms with less than 20 employees, value 2 for medium size firms between 20 and 99 employees, and value 3 for large firms with more than 100 employees.

Different types of ownership structure and legal status are often viewed as strongly correlated with firm performance, including whether a firm is state- or privately-owned, foreign- or domestic-owned and an open- or closed- 
shareholding, partnership or sole proprietorship (Barbera and Moores 2013; Baghdasaryan and la Cour 2013). Given that unregistered start-ups may have different ownership structures and legal statuses than registered start-ups, controlling for this is important. Here, legal status is a categorical variable indicating whether the enterprise is an open shareholding, a closed shareholding, a sole proprietorship, a partnership, a limited partnership, or any other form. In addition, whether the organisation is foreign- or domestic-owned is examined using a dummy variable with value 1 indicating if the share of the firm's ownership held by foreign individuals or enterprises is larger than $49 \%$ and 0 otherwise. Given that export-oriented firms are viewed as displaying higher levels of firm performance (La Porta and Shleifer 2008), export-orientation is also included as a control using a dummy variable with value 1 indicating firms exporting directly at least $1 \%$ of sales and 0 for those who sell only domestically.

Firm performance is also viewed as varying across economic sectors (Nabar and Yan 2013; Siqueira et al. 2014). Given that unregistered start-ups may be heavily concentrated in labour-intensive sectors with fewer returns to scale (Perry et al. 2007), controlling for sector is important. Sector is here a categorical variable indicating the sector of the firm (i.e., textiles, leather, garments, food, metals and machinery, electronics, chemicals and pharmaceuticals, wood and furniture, non-metallic and plastic materials, auto and auto components, other manufacturing, retail and wholesale trade, hotels and restaurants, and others).

Access to finance is strongly correlated with firm performance and given a burgeoning literature on how unregistered start-ups lack access to finance from formal lenders, this may well impact on future firm performance not only because they scaledown operations but also due to the high cost of informal loans and the limited financing available lead them to substitute (low skilled) labour for physical capital (Amaral and Quintin 2006; Cull et al. 2007). Access to bank loans or credit is here a dummy variable with value 1 indicating whether the firm has access to bank loans or to a line of credit to finance its activities and 0 otherwise.

Firm performance is also often associated with the level of technological innovation (Mansury and Love 2008). Given that most literature finds less innovation and adoption of new technologies in informal enterprises and that which does exist is more adaptation and imitation (Grimm et al. 2012; Kabecha 1998; Wunsch-Vincent et al. 2015), this needs controlling for when examining the impact of registration on future firm performance, especially given that some view this as the key reason for the productivity gap between developed and developing economies (Farrell 2004; Palmade 2005). Here, three rather limited control variables available in the WBES are used: quality certification, a dummy variable with value 1 indicating that the firm has an internationally-recognised certification and 0 otherwise; presence of a website, a dummy variable with value 1 when the firm uses a website for business related activities and 0 otherwise, and the use of e-mail, a dummy variable with value 1 when a firm uses e-mail with clients and suppliers and 0 otherwise.

Human capital factors, such as the educational level, skills and experience of the owners, managers and the workforce, the level of professionalism, and whether there is numerical flexibility in the workforce, are asserted to have a significant impact on firm performance (Black and Lynch 1996; Gennaiolo et al. 2013; La 
Porta and Shleifer 2014; Van der Sluis et al. 2005). Controlling for human capital factors is thus important, especially given that informality is associated with less productive workers due to more productive workers self-selecting formal over informal enterprises (Amaral and Quintin 2006; Dimova et al. 2008). Here, six control variables available in the WBES are used: top manager's experience, a continuous variable of the years of experience the top manager has working in the sector; temporary workers, a variable measuring the average number of temporary workers in the firm; permanent full-time workers, a continuous variable of the average number of permanent full-time workers in the firm; female full-time workers; and as a signal of professionalism, whether they use an external auditor, a dummy variable with value 1 indicating that the firm has its annual financial statement reviewed by an external auditor and 0 otherwise.

So too does the wider business environment determine firm performance. Two control variables are thus used measuring whether various facets of the business environment are a major constraint on the firm's activity, namely: transport, a dummy variable with value 1 indicating that transportation is a major constraint for the firm's activity and 0 otherwise, and electricity, a dummy variable with value 1 indicating that electricity supply is a major constraint for the firm's activity and 0 otherwise.

\section{Findings}

Of the formal enterprises with five or more employees surveyed in Turkey, 4\% started-up unregistered and stayed unregistered for an average of six months before registering. To analyse their firm performance relative to those registered from the outset, and since we are working under a normality assumption for our subsequent econometric estimation of determinants of firm performance, we examined the distributional properties of the three performance indicators (see the graphs in Appendix A). This displays near normality distribution particularly for sales and productivity growth rates. However, by expressing all the indicators in terms of log, we have introduced further smoothing of the distribution of our key variables to arrive at reliable estimates. The basic descriptive results of the firm performance are that formal enterprises unregistered at the commencement of operations had $13 \%$ higher annual sales growth than those registered from the outset $(20.4 \%$ compared with $18.1 \%), 39 \%$ higher annual productivity growth (18.1\% compared with $13.0 \%$ ), but $42 \%$ lower annual employment growth rates (3.6\% compared with $6.2 \%$ ). These descriptive statistics, however, do not control for other determinants of firm performance.

Since the early 1990's, there are a growing number of studies of the determinants of firm performance in Turkey (Taymaz 2009; Aydin et al. 2007; Yasar and Rejesus 2005). To explore the interrelationships among our dependent and independent variables analytically using a regression set up between informal entrepreneurship and firm performance, we estimated a Heckman regression model which enables us to handle the potential endogeneity discussed in the methodology (i.e., the endogenous choice of registration status by firms). Table 1 reveals that for these formal enterprises with five or more employees, starting-up unregistered is positively and significantly associated with higher subsequent sales and 
Table 1: Impacts of non-registration at start-up on firm performance: Heckman selection model

\begin{tabular}{|c|c|c|c|}
\hline Variable & $\begin{array}{l}\text { Log (sales growth) } \\
\text { Coefficient (s.e.) }\end{array}$ & $\begin{array}{l}\text { Log (employment growth ) } \\
\text { Coefficient (s.e.) }\end{array}$ & $\begin{array}{l}\text { Log } \\
\text { (productivity growth) } \\
\text { Coefficient (s.e.) }\end{array}$ \\
\hline Constant & $115.97 * * *(2.05)$ & $105.52 * * *(1.16)$ & $112.34 * * *(2.36)$ \\
\hline Unregistered & $3.01 * * *(0.84)$ & $-1.48 * * *(0.47)$ & $4.88 * * *(0.94)$ \\
\hline Firm age & $-0.12 * * *(0.02)$ & $-0.17 * * *(0.01)$ & $0.04(0.02)^{* *}$ \\
\hline Exporter & $02.43^{* * *}(0.50)$ & $-1.27 * * *(0.28)$ & $-1.10 * *(0.55)$ \\
\hline Foreign ownership & $2.52 * *(1.09)$ & $-1.40 * *(0.61)$ & $3.99 * * *(1.23)$ \\
\hline \multicolumn{4}{|l|}{ Workforce } \\
\hline Top manager years of experience & $-0.07 * * *(0.01)$ & $-0.01(0.01)$ & $-0.07 * * *(0.02)$ \\
\hline Temporary workers & $-0.06^{* *}(0.03)$ & $-0.01(0.02)$ & $-0.03(0.03)$ \\
\hline Permanent fulltime workers & $0.001(0.001)$ & $0.01 * * *(0.00)$ & $-0.01 * * *(0.00)$ \\
\hline Female ownership \% & $-0.78 *(0.46)$ & $-0.83 * * *(0.26)$ & $0.04(0.51)$ \\
\hline Credit access & $-0.14(0.44)$ & $1.38 * * *(0.25)$ & $-1.34 * * *(0.49)$ \\
\hline \multicolumn{4}{|l|}{ Major constraints } \\
\hline Transport constraint & $-2.43 * * *(0.77)$ & $-1.49 * * *(0.43)$ & $-1.47 *(0.86)$ \\
\hline Electricity constraint & $3.65^{* * *}(0.55)$ & $1.61 * * *(0.30)$ & $2.23 * * *(0.61)$ \\
\hline \multicolumn{4}{|l|}{ Innovation } \\
\hline Quality certification & $-0.78 *(0.48)$ & $-1.19 * * *(0.27)$ & $0.32(0.54)$ \\
\hline External auditor & $1.47 * * *(0.45)$ & $-1.39 * * *(0.25)$ & $3.08 * * *(0.50)$ \\
\hline Website & $1.34 * *(0.60)$ & $0.76^{* *}(0.33)$ & $0.77(0.67)$ \\
\hline E-mail & $0.87(0.72)$ & $-0.36(0.40)$ & $0.99(0.81)$ \\
\hline \multicolumn{4}{|l|}{ Firm size (RC: small) } \\
\hline Medium & $1.80 * * *(0.54)$ & $5.38 * *(0.30)$ & $-2.93 * * *(0.61)$ \\
\hline Large & $0.38(0.72)$ & $5.43 * * *(0.40)$ & $-4.60 * * *(0.82)$ \\
\hline \multicolumn{4}{|l|}{ Legal status (RC: open shareholding) } \\
\hline Closed shareholding & $4.31 * *(1.87)$ & $1.83(1.10)$ & $1.79(2.09)$ \\
\hline Sole partnership & $2.99(1.98)$ & $4.30 * * *(1.11)$ & $-2.15(2.22)$ \\
\hline Partnership & $0.36(2.45)$ & $0.04(1.37)$ & $-0.98(2.73)$ \\
\hline Limited partnership & $5.62 * * *(2.08)$ & $0.75(1.16)$ & $4.33 *(2.32)$ \\
\hline Other legal status & $14.66^{* * *(4.26)}$ & $-0.22(2.35)$ & $15.87 * * *(4.75)$ \\
\hline Rho & $-0.34 * * *(0.08)$ & $-0.04(0.15)$ & $-0.04(0.17)$ \\
\hline Lambda & $-10.25^{* * *}(2.46)$ & $-0.60(2.49)$ & $-1.41(5.56)$ \\
\hline Wald Chi-square statistic (p-value) & $235.39 * * *(0.00)$ & $951.08 * * *(0.00)$ & $228.61 * * *(0.00)$ \\
\hline No of observations & 2494 & 2494 & 2494 \\
\hline
\end{tabular}

$*, * *, * * *$ statistically significant at $1 \%, 5 \%$ and $10 \%$ respectively

productivity growth rates, but is negatively and significantly associated with lower employment growth rates. The average increase in sales growth is 3.01 percentage points and thus $17 \%$ higher for those formal enterprises starting-up unregistered compared with those registered from the outset (21.1\% compared with $18.1 \%)$, and productivity growth 2.36 percentage points and thus $18 \%$ higher $(15.36 \%$ compared with $13.0 \%$ ), although employment growth is 1.48 percentage points and thus $29 \%$ lower $(4.72 \%$ compared with $6.2 \%)$. These regression results are consistent with the descriptive bivariate relationships. Hence, hypothesis 1 is 
confirmed for two of the three performance indicators. This sits in contrast to a previous finding in Turkey based on a smaller database and using a total factor productivity (TFP) measure, which supports the view that unregistered firms are less productive (Taymaz 2009). Our estimation set up takes the joint estimation of the registration status (first-stage) and the performance indicator (second-stage) equations and the rho parameter reported shows the strength of dependence between the equations being stronger under the sales growth equation than the employment and productivity growth equations. The lambda parameter shows the

Table 2: Impact of years spent unregistered on firm performance: Heckman selection model

\begin{tabular}{|c|c|c|c|}
\hline Variable & $\begin{array}{l}\text { Log (sales growth) } \\
\text { Coefficient (s.e.) }\end{array}$ & $\begin{array}{l}\text { Log (employment growth ) } \\
\text { Coefficient (s.e.) }\end{array}$ & $\begin{array}{l}\text { Log } \\
\text { (productivity growth) } \\
\text { Coefficient (s.e.) }\end{array}$ \\
\hline Constant & $116.00 * * *(2.05)$ & $105.51 * * *(1.16)$ & $112.4 * * *(2.36)$ \\
\hline Years unregistered & $3.54 * * *(0.96)$ & $-0.80(0.54)$ & $4.81 * * *(1.08)$ \\
\hline Firm age & $-0.12 * * *(0.01)$ & $-0.18 * * *(0.01)$ & $0.04 * *(0.02)$ \\
\hline Exporter & $-2.47 * * *(0.50)$ & $-1.22 * * *(0.28)$ & $-1.19 * *(0.55)$ \\
\hline Foreign ownership & $2.54 * *(1.09)$ & $-1.41 * *(0.61)$ & $4.02 * * *(1.23)$ \\
\hline \multicolumn{4}{|l|}{ Workforce } \\
\hline Top manager years of experience & $-0.07 * * *(0.02)$ & $-0.00(0.01)$ & $-0.07 * * *(0.02)$ \\
\hline Temporary workers & $-0.06 * *(0.03)$ & $-0.001(0.002)$ & $-0.03(0.03)$ \\
\hline Permanent workers & $0.00(0.00)$ & $0.01 * * *(0.00)$ & $-0.004 * * *(0.001)$ \\
\hline Female ownership $\%$ & $-0.83 *(0.46)$ & $-0.79 * * *(0.26)$ & $-0.06(0.51)$ \\
\hline Credit access & $-0.16(0.44)$ & $1.39 * * *(0.25)$ & $-1.37 * *(0.49)$ \\
\hline \multicolumn{4}{|l|}{ Major constraints } \\
\hline Transport constraint & $-2.46^{* * *}(0.77)$ & $-1.49 * * *(0.43)$ & $-1.50 *(0.86)$ \\
\hline Electricity constraint & $3.60 * * *(0.55)$ & $1.62 * * *(0.30)$ & $2.16 * * *(0.61)$ \\
\hline \multicolumn{4}{|l|}{ Innovation } \\
\hline Quality certification & $-0.77(0.48)$ & $-1.20 * * *(0.27)$ & $0.33(0.54)$ \\
\hline External auditor & $1.43^{* * *}(0.45)$ & $-1.37 * * *(0.25)$ & $3.02 * * *(0.50)$ \\
\hline Website & $1.37 * *(0.60)$ & $0.74 * *(0.33)$ & $0.83(0.66)$ \\
\hline E-mail & $0.83(0.72)$ & $-0.32(0.40)$ & $0.91(0.80)$ \\
\hline \multicolumn{4}{|l|}{ Firm size (RC: small) } \\
\hline Medium & $1.84 * * *(0.54)$ & $5.38 * * *(0.30)$ & $-2.89 * * *(0.60)$ \\
\hline Large & $0.43(0.73)$ & $5.43 * * *(0.40)$ & $-4.55 * * *(0.82)$ \\
\hline \multicolumn{4}{|l|}{ Legal status (RC: open shareholding) } \\
\hline Closed shareholding & $4.36^{* *}(1.86)$ & $1.78 *(1.05)$ & $1.91(2.09)$ \\
\hline Sole partnership & $2.97(1.98)$ & $4.24 * * *(1.11)$ & $-2.11(2.22)$ \\
\hline Partnership & $0.33(2.45)$ & $0.03(1.37)$ & $-0.99(2.74)$ \\
\hline Limited partnership & $5.59 * * *(2.07)$ & $0.70(1.17)$ & $4.35 *(2.32)$ \\
\hline Other legal status & $14.67 * * *(4.26)$ & $-0.17(2.35)$ & $15.85 * * *(4.75)$ \\
\hline Rho & $-0.34 * * *(0.08)$ & $-0.02(0.18)$ & $-0.04(0.16)$ \\
\hline Lambda & $-10.1 * * *(2.52)$ & $-0.40(3.02)$ & $-1.36(5.54)$ \\
\hline Wald Chi-square statistic (p-value) & $235.8^{* * * *(0.00)}$ & $942.7 * * *(0.00)$ & $221.2 * * *(0.00)$ \\
\hline No of observations & 2494 & 2494 & 2494 \\
\hline
\end{tabular}

$*, * *, * * *$ statistically significant at $1 \%, 5 \%$ and $10 \%$ respectively 
importance of correcting for sample selection bias and it is again significant for the sales growth equation but not for the employment and productivity growth equations.

Table 2, meanwhile, examines whether the length of time that these formal enterprises spent unregistered influences their firm performance. Supporting hypothesis 2 , we find that controlling for other key determinants of firm performance and the endogenous choice of registration status, enterprises spending longer unregistered display significantly higher levels of both sales and productivity growth, and that the log for employment growth is statistically insignificant, and thus neither refutes our conjecture nor supports the opposite view that links years spent unregistered negatively with firm performance. For each extra year of nonregistration, sales growth is 3.54 percentage points higher, and productivity growth 4.81 percentage points higher, both of which are significant, although employment growth is 0.8 percentage points lower, although this is not significant.

Moreover, the observation that there are no differences between Tables 1 and 2 in terms of the sign and statistical significance of all the other additional explanatory variables displays that our results are robust. Whether we use the dummy/ binary variable indicating registration status as a regressor, or the number of years spent unregistered before registration (which is a continuous variable), the key findings do not change. As indicated by the rho, lambda parameters and also a likelihood ratio (LR) test for the independence of equations, standard OLS are used to check robustness further by estimating particularly those equations pertaining to employment and productivity growth where the selectivity bias problem is less severe and the dependence between the selection and the primary equation is limited. ${ }^{1}$ All the specified models reported in Tables 1 and 2 have strong explanatory power of the variation of all the three firm performance indicators as shown by the diagnostics. This is evident from the large Wald chisquare statistic and its associated p-value which is statistically significant.

\section{Discussion and conclusions}

This analysis of WBES data reveals that in Turkey, 1 in 25 of the formal private sector businesses with five employees or more surveyed had started-up unregistered and of these, the average length of time that they spent unregistered was six months. For these formal enterprises, starting-up unregistered is positively and significantly associated with higher subsequent sales and productivity growth rates, but is negatively and significantly associated with lower employment growth rates. Moreover, the longer they spend unregistered, the significantly higher is their sales and productivity growth rates, and the log for employment growth is statistically insignificant, thus neither refuting our conjecture nor supporting the opposite view that links years spent unregistered negatively with firm performance. No significant associations are thus identified between length of nonregistration and lower firm performance. Overall, therefore, evidence is found to support hypothesis 1 in both sales and productivity growth rates, but not

\footnotetext{
${ }^{1}$ These results can be provided upon request.
} 
employment growth rates, whilst evidence is found to confirm hypothesis 2 that length of nonregistration improves firm performance in terms of sales and productivity growth rates, and no evidence to refute it.

Our findings have important implications. They contribute to the advancement of the shift away from negative representations of informal entrepreneurship by displaying that formal enterprises in Turkey that began unregistered and only later registered, and those spending longer unregistered before registering, do not display weaker subsequent firm performance than those registered from the outset. This confirms the two hypotheses posed in this study. Instead, being unregistered at start-up significantly boosts subsequent sales and productivity growth, as does a lengthier period of being unregistered. This finding that those unregistered at startup display better subsequent sales and productivity growth figures, but lower employment growth rates, suggests that those delaying business registration, used this period to establish the conditions to become more capital-intensive and less labour-intensive once they registered. These results also display that for these formal enterprises, the benefits of being nonregistered at start-up outweigh the benefits of registering at the outset, reflected in the higher subsequent firm performance of the enterprises starting-up, and spending longer, unregistered. This intimates that the deficiencies of the formal institutional environment have a key role to play in determining the prevalence of informal entrepreneurship.

This has important policy implications. For many years, based on a negative depiction of informal entrepreneurship as poorer performing, the conventional policy approach was to seek its eradication. Drawing on the Allingham and Sandmo (1972) rational economic actor approach that seeks to change the costs of operating informally and benefits of operating formally, governments predominantly increased the costs of informality by increasing the penalties. This paper suggests that there is also a need to reduce the costs and improve the benefits of registration since the benefits currently appear insufficient to outweigh the benefits of nonregistration at start-up in Turkey, reflected in the weaker subsequent firm performance. This requires a simplification of registration, and a reduction in the costs and improvement in the benefits of registration (Maloney 2004; McKenzie and Woodruff 2006). Indeed, in terms of the ease of starting a business, Turkey in 2012 at the time of this survey was ranked 61 st out of 183 countries, since this requires six procedures, takes six days, costs $11.2 \%$ of income per capita and requires a minimum of $8.7 \%$ of income per capita (Eurofound 2013).

This means that there is (though indirectly) a need to deal with the systemic formal institutional deficiencies that lead entrepreneurs to decide to start-up their ventures on an unregistered basis. In recent years, recognition has emerged, grounded in institutional theory, that informal entrepreneurs are also often social actors (De Castro et al. 2014; Webb et al. 2009, 2013, 2014; Williams and Shahid 2015). Based on this view that informal entrepreneurship arises when entrepreneurs' norms, values and beliefs are not in symmetry with the prescriptions of formal institutions, there is thus a need to tackle the formal institutional imperfections that provide little incentive for entrepreneurs to register and adhere to the laws and regulations of the formal institutional environment. These alterations required in formal institutions are of two types. On the one hand, tax fairness, procedural justice and redistributive justice needs to be improved. Fairness here 
refers to the extent to which entrepreneurs believe they are paying their fair share compared with others (Wenzel 2004), redistributive justice to whether they receive the goods and services they feel that they deserve given the taxes that they pay (Richardson and Sawyer 2001) and procedural justice to the degree to which they believe that the tax authority has treated then in a respectful, impartial and responsible manner (Braithwaite and Reinhart 2000; Murphy 2005). On the other hand, it requires greater social protection, less public sector corruption and more effective social transfer mechanisms, all of which have been shown to be strongly correlated with a reduced prevalence of informal entrepreneurship (Autio and Fu 2015; Dau and Cuervo-Cazurra 2014; Klapper et al. 2007; Thai and Turkina 2014).

Nevertheless, there are limitations to this study. Only one country is here analysed and this paper reveals only that formal enterprises with five more employees who started-up unregistered witness higher subsequent sales and productivity growth than those that registered from the outset. We can therefore only assert that those formal enterprises that started unregistered outperform those registered from the outset; we cannot argue that unregistered enterprises as a whole outperform registered enterprises as a whole. Nevertheless, some very tentative clues exist that this may be worth investigating in future research. Similar to formal enterprises that delay registration, they operate under the same conditions that boost firm performance, including being able to avoid taxes, burdensome regulations and corrupt public sector officials. Consequently, future research could investigate the firm performance of unregistered compared with registered enterprises, especially given the current weak evidence to support the poorer performance thesis of unregistered enterprises (e.g., La Porta and Shleifer 2008). A further limitation of this study is that it cannot evaluate whether the reasons for entrepreneurs operating unregistered (e.g., whether they are simply awaiting registration, deliberately testing the venture's viability before registering, or have no intent to register) or the reasons enterprises register (e.g., better access to finance or markets, fewer bribes, better opportunities with formal firms, more access to government programs), influence subsequent firm performance. Future research needs to do this, not least in order to tailor policy measures. And finally, these findings suggest that a more rigorous evaluation of other assumptions regarding the negative and potentially positive impacts of informal entrepreneurship is now required, such as whether customers benefit from more affordable goods and services.

In sum, this paper has revealed that formal enterprises which delayed registration outperform those which started-up registered in Turkey, calling into question the long-standing depiction of informal entrepreneurship as poorer performing. If this now stimulates similar research in other countries and global regions, and a critical evaluation of other supposedly negative and positive impacts of informal entrepreneurship, then one intention will have been fulfilled. If this then leads to questions being raised about what policy approaches should be pursued towards informal entrepreneurship, this paper will have achieved its fuller intention. What is certain, however, is that the until now dominant negative representation of informal entrepreneurship as poorly performing can no longer simply be assumed without providing any evidence-base to support such an assertion. 


\section{Appendix: Distribution of Performance Indicators}
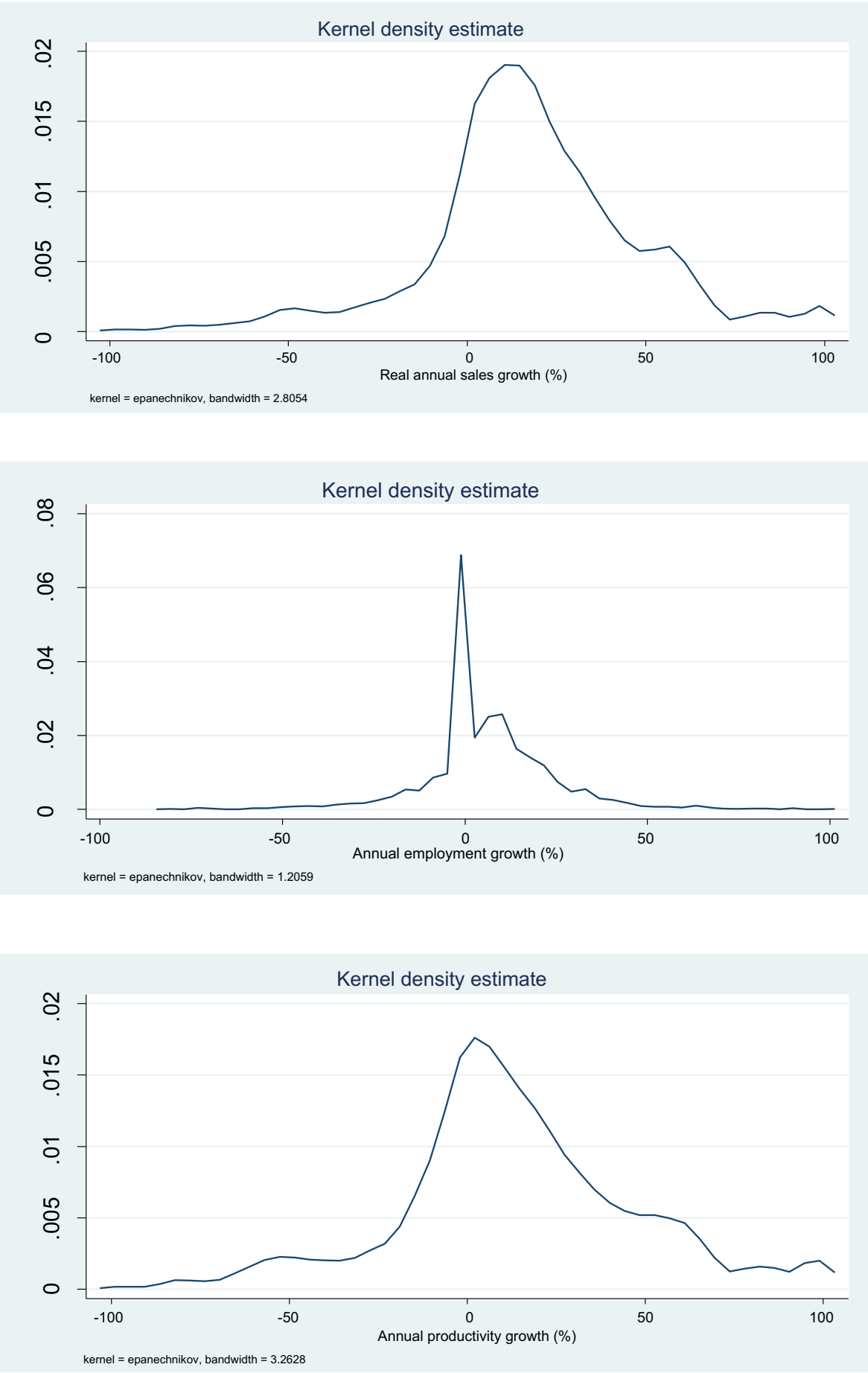
Open Access This article is distributed under the terms of the Creative Commons Attribution 4.0 International License (http://creativecommons.org/licenses/by/4.0/), which permits unrestricted use, distribution, and reproduction in any medium, provided you give appropriate credit to the original author(s) and the source, provide a link to the Creative Commons license, and indicate if changes were made.

\section{References}

Allingham, M., \& Sandmo, A. (1972). Income tax evasion: a theoretical analysis. Journal of Public Economics, 1(2), 323-338.

Amaral, P. S., \& Quintin, E. (2006). A competitive model of the informal sector. Journal of Monetary Economics, 53, 1541-1553.

Autio, E., \& Fu, K. (2015). Economic and political institutions and entry into formal and informal entrepreneurship. Asia Pacific Journal of Management, 32(1), 67-94.

Aydin, N., Sayim, M., \& Yalama, A. (2007). Foreign ownership and firm performance: evidence from Turkey. International Research Journal of Finance and Statistics, 11, 103-110.

Baghdasaryan, D., \& la Cour, L. (2013). Competition, ownership and productivity: a panel analysis of Czech firms. Journal of Economics and Business, 69, 86-100.

Bajada, C., \& Schneider, F. (2005). The shadow economies of the Asia-Pacific. Pacific Economic Review, 10, 379-401.

Barbera, F., \& Moores, K. (2013). Firm ownership and productivity: a study of family and non-family SMEs. Small Business Economics, 40, 953-976.

Barbour, A., \& Llanes, M. (2013). Supporting people to legitimise their informal businesses. York: Joseph Rowntree Foundation.

Baumol, W. J. (1990). Entrepreneurship: productive, unproductive and destructive. Journal of Political Economy, 98, 893-921.

Black, S. E., \& Lynch, L. M. (1996). Human-capital investments and productivity. The American Economic Review, 25, 263-267.

Braithwaite, V., \& Reinhart, M. (2000). The taxpayers' charter: does the Australian tax office comply and who benefits. Canberra: Centre for Tax System Integrity Working Paper no.1, Australian National University.

Castells, M., \& Portes, A. (1989). World underneath: the origins, dynamics and effects of the informal economy. In A. Portes, M. Castells, \& L. Benton (Eds.), The informal economy: studies in advanced and less developing countries (pp. 1-19). Baltimore: John Hopkins University Press.

Cross, J. C. (2000). Street vendors, modernity and postmodernity: conflict and compromise in the global economy. International Journal of Sociology and Social Policy, 20(1), 29-51.

Cull, R., McKenzie, D., \& Woodruff, C. (2007). Experimental evidence on returns to capital and access to finance in Mexico. Washington DC: World Bank.

Dau, L. A., \& Cuervo-Cazurra, A. (2014). To formalize or not to formalize: entrepreneurship and pro-market institutions. Journal of Business Venturing, 29, 668-686.

Davis, M. (2006). Planet of slums. London: Verso.

De Beer, J., Fu, K., \& Wunsch-Vincent, S. (2013). The informal economy, innovation and intellectual property: concepts, metrics and policy considerations. Geneva: Economic Research Working Paper no. 10, World Intellectual Property Organization.

De Castro, J. O., Khavul, S., \& Bruton, G. D. (2014). Shades of grey: how do informal firms navigate between macro and meso institutional environments? Strategic Entrepreneurship Journal, 8, 75-94.

De Mel, S., McKenzie, D., \& Woodruff, C. (2012). The demand for, and consequences of formalization among informal firms in Sri Lanka. Washington DC: Policy Research Working Paper 5991, World Bank.

De Soto, H. (1989). The other path: the economic answer to terrorism. London: Harper and Row.

De Soto, H. (2001). The mystery of capital: why capitalism triumphs in the west and fails everywhere else. London: Black Swan.

Dimova, R., Nordman, C. J., \& Roubaud, F. (2008). Allocation of labour in urban West Africa: implication for development policies. Bonn: IZA Discussion Paper No. 3558, IZA.

Eurofound (2013). Tackling undeclared work in Turkey. Dublin: Eurofound.

Fajnzylber, P., Maloney, W., \& Montes Rojas, G. (2009). Releasing constraints to growth or pushing on a string? Policies and performance of Mexican micro-firms. Journal of Development Studies, 45, 1027-1047.

Farrell, D. (2004). The hidden dangers of informal economy. McKinsey Quarterly, 3, 27-37.

Franck, A. K. (2012). Factors motivating women's informal micro-entrepreneurship: experiences from Penang, Malaysia. International Journal of Gender and Entrepreneurship, 4(1), 65-78.

Geertz, C. (1963). Old societies and new states: the quest for modernity in Asia and Africa. Glencoe, IL: Free Press. 
Gennaiolo, N., La Porta, R., Lopez-de-Silanes, F., \& Shleifer, A. (2013). Human capital and regional development. Quarterly Journal of Economics, 128(1), 105-164.

Gërxhani, K. (2004). The informal sector in developed and less developed countries: a literature survey. Public Choice, 120(3/4), 267-300.

Gilbert, A. (1998). The Latin American City. London: Latin American Bureau.

Grimm, M., Knorringa, P., \& Lay, J. (2012). Constrained gazelles: high potentials in West Africa's informal economy. World Development, 40(7), 1352-1368.

Hsieh, C-T., \& Olken, A. (2014). The missing 'Middle', National Bureau of Economic Research (NBER) Working Paper W19966.

ILO (2007). The decent work agenda in Africa 2007-15. Geneva: ILO.

ILO (2013). Women and men in the informal economy: statistical picture. Available at http://aborsta.ilo. org/informal_economy_E.html. Last accessed 10 Jan 2014.

ILO (2014). Transitioning from the informal to the formal economy. Report V (1), International Labour Conference, 103rd Session (2014). Geneva: ILO.

Kabecha, W. W. (1998). Technological capability of the micro-enterprises in Kenya's informal sector. Technovation, 19(2), 117-126.

Ketchen, D. J., Ireland, R. D., \& Webb, J. W. (2014). Towards a research agenda for the informal economy: a survey of the strategic entrepreneurship Journal's editorial board. Strategic Entrepreneurship Journal, 8, 95-100.

Kistruck, G. M., Webb, J. W., Sutter, C. J., \& Bailey, A. V. G. (2015). The double-edged sword of legitimacy in base-of-the-pyramid markets. Journal of Business Venturing, 30(3), 436-451.

Klapper, L., Amit, R., Guillen, M. F., \& Quesdada, J.-M. (2007). Entrepreneurship and firm formation across countries. Washington DC: Policy Research Working Paper series 4313, World Bank.

La Porta, R., \& Shleifer, A. (2008). The unofficial economy and economic development. Brookings Papers on Economic Activity, 47(1), 123-135.

La Porta, R., \& Shleifer, A. (2014). Informality and development. Journal of Economic Perspectives, 28(3), $109-126$.

Leal Ordóñez, J. C. (2014). Tax collection, the informal sector and productivity. Review of Economic Dynamics, 17, 262-286.

Lewis, A. (1959). The theory of economic growth. London: Allen and Unwin.

Lewis, W. W. (2004). The power of productivity: wealth, poverty, and the threat to global stability. Chicago: University of Chicago Press.

London, T., Esper, H., Grogan-Kaylor, A., \& Kistruck, G. M. (2014). Connceting poverty to purchase in informal markets. Strategic Entrepreneurship Journal, 8, 37-55.

Maloney, W. F. (2004). Informality revisited. World Development, 32(7), 1159-1178.

Mansury, M. A., \& Love, J. H. (2008). Innovation, productivity and growth in US business services: a firmlevel analysis. Technovation, 28(1-2), 52-62.

McKenzie, D., \& Sakho, Y. S. (2010). Does it pay firms to register for taxes? The impact of formality on firm profitability. Journal of Development Economics, 91(1), 15-24.

McKenzie, D., \& Woodruff, C. (2006). Do entry costs provide an empirical basis for poverty traps? Evidence from microenterprises. Economic Development and Cultural Change, 55(1), 3-42.

McKinsey Global Institute (2003). Turkey: making the productivity and growth breakthrough. New York: McKinsey.

Meagher, K. (2010). Identity economics: social networks and the informal economy in Nigeria. New York: James Currey.

Murphy, K. (2005). Regulating more effectively: the relationship between procedural justice, legitimacy and tax non-compliance. Journal of Law and Society, 32(4), 562-589.

Nabar, M., \& Yan, K. (2013). Sector-level productivity, structural change and rebalancing in China. Washington DC: IMF Working Paper no. 240, IMF.

North, D. C. (1990). Institutions, institutional change and economic performance. Cambridge: Cambridge University Press.

Nwabuzor, A. (2005). Corruption and development: new initiatives in economic openness and strengthened rule of law. Journal of Business Ethics, 59(1/2), 121-138.

Palmade, V. (2005). Rising informality. Washington DC: Viewpoint Series note 298, Private Sector Development, World Bank.

Palmer, R. (2007). Skills development, the enabling environment and informal micro-enterprise in Ghana. Edinburgh: University of Edinburgh.

Perry, G. E., \& Maloney, W. F. (2007). Overview - informality: exit and exclusion. In G. E. Perry, W. F. Maloney, O. S. Arias, P. Fajnzylber, A. D. Mason, \& J. Saavedra-Chanduvi (Eds.), Informality: exit and exclusion (pp. 1-20). Washington DC: World Bank. 
Perry, G. E., Maloney, W. F., Arias, O. S., Fajnzylber, R., Mason, A. D., \& Saavedra-Chanduvi, J. (2007). Informality: exit and exclusion. Washington, DC: World Bank.

Puffer, S., McCarthy, D., \& Boisot, M. (2010) Entrepreneurship in Russia and China: the impact of formal institutional voids. Entrepreneurship Theory and Practice, 34(3), 441-467.

Richardson, M., \& Sawyer, A. (2001). A taxonomy of the tax compliance literature: further findings, problems and prospects. Australian Tax Forum, 16(2), 137-320.

Schneider, F., \& Williams, C. C. (2013). The shadow economy. London: Institute of Economic Affairs.

Siqueira, A. C. O., Webb, J. W., \& Bruton, G. D. (2014). Informal entrepreneurship and industry conditions. Entrepreneurship Theory and Practice. doi:10.1111/etap.12115.

Slavnic, Z. (2010). Political economy of informalisation. European Societies, 12(1), 3-23.

Sutter, C. J., Webb, J. W., Kistruck, G. M., \& Bailey, A. V. G. (2013). Entrepreneurs' responses to semi-formal illegitimate institutional arrangements. Journal of Business Venturing, 28(5), 743-758.

Taiwo, O. (2013). Employment choice and mobility in multi-sector labour markets: theoretical model and evidence from Ghana. International Labour Review, 152(3-4), 469-492.

Taymaz, E. (2009). Informality and productivity differentials between formal and informal firms in Turkey. Istanbul: Department of Economics, Middle East Technical University.

Thai, M. T. T., \& Turkina, E. (2014). Macro-level determinants of formal entrepreneurship versus informal entrepreneurship. Journal of Business Venturing, 29(4), 490-510.

Tonoyan, V., Strohmeyer, R., Habib, M., \& Perlitz, M. (2010). Corruption and entrepreneurship: how formal and informal institutions shape small firm behaviour in transition and mature market economies. Entrepreneurship Theory and Practice, 34(5), 803-831.

Van der Sluis, J., Van Praag, M., \& Vijverberg, W. (2005). Entrepreneurship selection and performance: a metaanalysis of the impact of education in developing economies. The World Bank Economic Review, 19(2), 225-261.

Vu, T.T. (2014). Institutional Incongruence and the Informal Economy: an Empirical Analysis. Paper presented at the European Public Choice Society meeting: Cambridge. http://www.econ.cam.ac. uk/epcs2014/openconf/modules/request.php? module=oc_programandaction=summary.phpandid=54.

Webb, J. W., Tihanyi, L., Ireland, R. D., \& Sirmon, D. G. (2009). You say illegal, I say legitimate: entrepreneurship in the informal economy. Academy of Management Review, 34(3), 492-510.

Webb, J. W., Bruton, G. D., Tihanyi, L., \& Ireland, R. D. (2013). Research on entrepreneurship in the informal economy: framing a research agenda. Journal of Business Venturing, 28, 598-614.

Webb, J. W., Ireland, R. D., \& Ketchen, D. J. (2014). Towards a greater understanding of entrepreneurship and strategy in the informal economy. Strategic Entrepreneurship Journal, 8(1), 1-15.

Wenzel, M. (2004). An analysis of norm processes in tax compliance. Journal of Economic Psychology, 25(2), 213228.

Williams, C. C. (2009). The motives of off-the-books entrepreneurs: necessity- or opportunity-driven? International Entrepreneurship and Management Journal, 5(2), 203-217.

Williams, C. C. (2015a). Explaining cross-national variations in the scale of informal employment: an exploratory analysis of 41 less developed economies. International Journal of Manpower, 36(2), 118-135.

Williams, C. C. (2015b). Out of the margins: classifying economies by the prevalence and character of employment in the informal economy. International Labour Review, 154(3), 331-352.

Williams, C. C., \& Gurtoo, A. (2012). Evaluating competing theories of street entrepreneurship: some lessons from Bangalore, India. International Entrepreneurship and Management Journal, 8(4), 391-409.

Williams, C. C., \& Horodnic, I. (2015). Evaluating the prevalence of the undeclared economy in central and Eastern Europe: an institutional asymmetry perspective. European Journal of Industrial Relations, 21(4), 389-406.

Williams, C. C., \& Martinez-Perez, A. (2014a). Is the informal economy an incubator for new enterprise creation? A gender perspective. International Journal of Entrepreneurial Behaviour and Research, 20(1), 4-19.

Williams, C. C., \& Martinez-Perez, A. (2014b). Why do consumers purchase goods and services in the informal economy? Journal of Business Research, 67(5), 802-806.

Williams, C. C., \& Shahid, M. (2015). Informal entrepreneurship and institutional theory: explaining the varying degrees of (in)formalisation of entrepreneurs in Pakistan. Entrepreneurship and Regional Development. doi:10.1080/08985626.2014.963889.

Williams, C. C., \& Youssef, Y. (2015). Theorizing entrepreneurship in the informal sector in urban Brazil: a product of exclusion or exit? Journal of Entrepreneurship, 24(2), 148-168.

Williams, C. C., Nadin, S., \& Rodgers, P. (2012). Evaluating competing theories of informal entrepreneurship: some lessons from Ukraine. International Journal of Entrepreneurial Behaviour and Research, 18(5), $528-543$. 
Williams, C. C., Nadin, S., Newton, S., Rodgers, P., \& Windebank, J. (2013). Explaining off-the-books entrepreneurship: a critical evaluation of competing perspectives. International Entrepreneurship and Management Journal, 9(3), 447-463.

Williams, C. C., Shahid, M., \& Martinez, A. (2015). Determinants of the level of informality of informal micro-enterprises: some evidence from the city of Lahore, Pakistan. World Development. doi:10.1016/j. worlddev.2015.09.003.

Wunsch-Vincent, S., de Beer, J., \& Fu, K. (2015). What we know and do not know about innovation in the informal economy. In E. Kraemer-Mbula \& S. Wunsch-Vincent (Eds.), The informal economy in developing nations: hidden engine of innovation?: new economic insights and policies (pp. 142-160). Cambridge: Cambridge University Press.

Yasar, M., \& Rejesus, R. (2005). Exporting status and firm performance: evidence from a matched sample. Economics Letters, 88(3), 397-402. 